This is the post print version of the article, which has been published in Studies in higher education. 2018, 43 (10), 1778-1791.https://doi.org/10.1080/03075079.2018.1526773

\title{
PISA and the criticism of Finnish education: justifications used in the national media debate \\ Marjaana Rautalin

\begin{abstract}
This study examines the Finnish media debate surrounding the OECD-led PISA Study during the periods 2001-2009 and 2013-2014. The empirical focus of the study is on how debaters dissatisfied with Finnish education have justified their criticism in the context of debating PISA and how the justifications used have changed as Finland's PISA ranking has changed. The study argues that as Finland's ranking in PISA 2012 apparently deteriorated, this lent great support to the critical arguments voiced in public in Finland. Criticism no longer needed to be based on the proclamation in public of the international success of the Finnish education system which had previously been an integral part of the PISA discussion. Instead it was legitimate to note the deterioration in Finland's PISA ranking. This poorer ranking was used as an authority with other sources of legitimate information when proposing what various reforms Finland should undertake. Of especially great help in publicizing such views was that the national political elite, which had long succeeded in dominating the national public PISA debate, were unable in the face of the changed ranking to offer convincing explanations for this change in the ranking or to propose what measures should be undertaken in consequence. That is, the obvious decline in the PISA ranking and the inability of the previously so well placed political elite to manage the public debate on the changed PISA rankings fueled a critical discussion on education which was rhetorically much more challenging in the earlier publicity surrounding PISA.
\end{abstract}




\section{PISA and the criticism of Finnish education: justifications used in the national media debate}

Marjaana Rautalin, Faculty of Social Sciences and Humanities, University of Tampere

\section{Introduction}

In 2013 the Organisation for Economic Co-operation and Development (OECD) reported a significant decline in Finnish pupils' learning outcomes. According to the OECD-led Programme for International Student Assessment, known as the PISA Study ${ }^{1}$, average mathematical literacy among Finnish school students ranked twelfth among the 65 countries participating in the PISA 2012 assessment. In 2003, when mathematics had been the focus of the study, Finland came second. The national average score in mathematics has decreased significantly since the 2003 assessment. According to the OECD, reading and science literacy have also deteriorated markedly (MINEDU, 2013; OECD, 2013).

This news about Finnish students' declining learning outcomes is interesting as for many years Finland basked in educational glory due to its high ranking in PISA (OECD, 2001, 2004, 2007, 2010). The success achieved in earlier assessments turned the Finnish education system, more precisely the Finnish comprehensive school system, into a success story (Sahlberg, 2011; Takayama, Waldow, \& Sung, 2013), resulting in hundreds of international education experts and policymakers visiting Finland and Finnish schools annually (Winstanley, 2012). In the Finnish nation-state context, Finland's success in PISA was attributed in part to the successful Finnish education policy and to the high level of expertise among Finnish teachers. In its official accounts, the Finnish Ministry of Education and Culture (MINEDU) and the National Board of Education (NBE) specifically highlighted the national education policy reforms such as the Finnish comprehensive school reform introduced in the 1970's as being the secret of the national PISA success. For instance, in the Ministry report of 2009 entitled The Finnish Education System and PISA the national PISA success factors are discussed as follows:

The results of PISA are not all there is to education, but the continuous success of Finnish students can be seen to attest to a successful implementation of the objectives of the Finnish comprehensive school reform since the early 1970 s. (...) While willingly admitting the need for continuous evaluation and development of the Finnish education system, we are pleased to conclude that current empirical evidence, combined with the moral argument for educational equality still speak

\footnotetext{
${ }^{1}$ PISA is an OECD-led comparative study surveying the competencies and skills of 15-year-olds at the end of compulsory schooling in the key subjects: reading, mathematics and science. Since 2000 it has been conducted triennially with the results being published the following year.
} 
strongly for a comprehensive school with high national standards and well-functioning student support. (Kupiainen, Hautamäki, \& Karjalainen, 2009, pp. 60-61)

As Finland's PISA ranking was decidedly lower in the 2012 assessment, it is justified to study how this decline in ranking affected the ways in which the status of Finnish education was debated among the Finnish public. Earlier research has revealed that good results in international comparisons are beneficial for actors supporting the status quo, that is, the system as it is, whereas poor results achieved in such comparisons usually favour reformists, actors wishing to justify the necessity of the reforms by the poor ranking of their own country. The latter has been the case especially in Germany, where the poor results achieved in PISA's early rounds provoked a public outcry or 'shock' and a call for massive reforms.

According to Ertl (2006), before PISA, German policymakers were mainly lukewarm about international learning assessment. Nor did the findings of earlier comparative studies attract much attention in the German media. As the first PISA results published in 2001 revealed that in all the areas assessed students in German schools performed distinctly more poorly than their peers in other OECD countries and that in Germany educational success is most closely related to students' socioeconomic and ethnic backgrounds (Deutsches PISA-Konsortium, 2001), the political debate changed drastically. According to Ertl, the disclosure of the PISA findings brought about a broad societal consensus that educational reforms were indispensable (Ertl, 2006, p. 621). However, there was considerable variation in the types of reforms called for. For instance, the German Federal Ministry of Education and Research (BMBF), a body which in Germany shares responsibility with the Länder in the fields of non-school vocational training and training assistance, took the poor PISA results as a reason to commission an expert group tasked with raising national standards in education. This work initiated by the BMBF resulted in the so-called 'Klieme Report', which, according to Ertl, later became the conceptual basis of the development of national standards in education in Germany (2006, p. 621). The German employers' union and trade union associations came up with other calls for reform. In a joint statement presented by the unions to the BMBF, ten distinct reforms were proposed ostensibly to improve quality, equality and fostering of talent in national education (Ertl, 2006, p. 624).

Paradoxically, in countries that have performed relatively well in PISA, the assessment has likewise triggered debates about the status of national education. This has been the case, for instance, in Japan. According to Takayama (2008), Japan's fall in the reading literacy rankings from eight in PISA 2000 to fourteen in PISA 2003 sparked a fierce public debate on the appropriateness of the reforms under way at that time. Takayama argues that when Japan's PISA 2003 results were released, the Japanese media in particular generated a moral panic over the status of Japanese basic education while emphasizing how the allegedly declining national educational outcomes were likely to jeopardize Japan's future competitiveness. This national PISA panic created by the Japanese media was further capitalized on by the Japanese Ministry of Education, particularly by the then Minister of Education, when he replaced two ongoing education policy reforms with two utterly different reforms 
promoted by the Ministry. By so doing, the Minister attempted to show how the Ministry would take full responsibility for Japanese teenagers' supposedly declining learning outcomes. In point of fact, according to Takayama, the Minister of Education only responded to the Japanese then Prime Minister's call to rationalize and thus 'neoliberalize' Japanese education but, more importantly, to reestablish the Ministry of Education's political legitimacy at a time of increasing neoliberal state restructuring (Takayama, 2008, pp. 387, 400-402).

As will be discussed later in this article, there is a wide range of studies demonstrating similar policy struggles triggered by PISA. These studies are interesting and contribute to our understanding of how international assessment information such as that produced in PISA is used to debate the status of national education systems and to call for reforms. Yet none of the studies so far has accounted for how international comparisons such as PISA and the results achieved in these can benefit different parties and arguments at different times. With this study, my aim is to fill in this gap in the existing research.

I examine how change in the national PISA ranking can afford a useful tool or a resource for actors previously experiencing difficulties in defending their viewpoints in the national PISA debates. Earlier research (Rautalin, 2014) has shown that when Finland was ranked high in PISA, the ensuing public discussion on the PISA findings turned conveniently into a mantra on the excellence of Finnish basic education by international standards and what the secret of this success might be. Such a negotiating position was extremely favourable to the central administration, MINEDU and the NBE, which in Finland are jointly responsible for the evaluation of education and for the overall strategic direction. The representatives of the central administration succeeded in assuring the public at large that Finland's PISA success was largely attributable to Finnish education policy, and that if there were problems in Finnish education, these were due to the activities of actors outside central government (see Rautalin \& Alasuutari, 2009). Once the notion had been inculcated in the Finnish public (and to a great extent also in other national publics) that Finland's success in PISA was primarily due to a successful national education policy, the opposite view - which was extremely critical of the national education and policy - became very difficult to promote. This said, it does not mean that no criticism was expressed towards Finnish education. Quite the opposite. Existing research (Rautalin, 2014; Rautalin \& Alasuutari, 2007) has revealed that in spite of success achieved in PISA, in the Finnish public a considerable number of arguments were evinced attempting to show that there are still problems in Finnish education. However, expressing views in such utter opposition to this public conception required of those propounding them a carefully considered rhetoric by means of which to assure the public that, in spite of success in PISA, Finnish education is not problem-free.

In this study, I examine this kind of rhetorical battling surrounding PISA. I examine how actors dissatisfied with Finnish education have justified their criticism at different times in the context of debating PISA. My analysis pays special attention to the means of assurance that are used to legitimize the criticism expressed. As empirical data, I use texts invoking PISA appearing in Finnish 
quality media outlets. The questions posed to the data are: How do actors dissatisfied with Finnish education justify their criticism in the context of debating PISA? How is PISA, together with other sources of information, invoked to legitimize the criticism expressed? How does the change in national PISA ranking figure in the justifications put forward?

The rest of this article is organized as follows. First, I will introduce the theoretical frameworks the study draws on. Then the empirical data and methods will be introduced. After that, I move on to discuss the findings of my empirical investigation. In my conclusion, I consider the overall role of the international comparisons such as PISA in domestic policies, particularly the conditions under which they become parties to national policy-making.

\section{IOs and national policy-making}

With my analysis of the ways in which PISA and the quality of Finnish education are debated in the national context my aim is also to contribute to the wider theoretical discussion on the role of international organizations (IOs) and their knowledge production in domestic policy-making. This theme has inspired a wide range of scholars. Education research in particular has taken an interest in the prominent role of the OECD and its special projects like PISA in national education policies. Much of this research centres around the controversies PISA has triggered in local contexts, battles in which not only politicians but also other interested actors argue over how to interpret the national PISA results and what lessons could be drawn from the study (Afonso \& Costa, 2009; Fredriksson, Holzer, McCluskey-Cavin, \& Taube, 2009). The literature claims that it is typical of such debates that when referring to PISA each stakeholder picks out elements from the study that best support the objectives of the party in voice. Consequently, it has been argued, PISA becomes transformed into a finite number of simplified statements (Mangez \& Hilgers, 2012; Pons, 2012), arguments intended convince the other parties of the state of national education systems and of appropriate policy measures. This means that the end result may only be a far cry from the original ideas as promoted by the OECD (Bonal \& Tarabini, 2013) and that there are considerable differences between countries in which the same policy idea or model has been introduced (Bieber \& Martens, 2011; Martens \& Niemann, 2013).

Attention in recent years has also been paid to the 'reference societies' to which PISA has given rise and to the use made of these in the promotion of domestic policy reforms. The term reference society was originally coined by the macro-sociologist Reinhard Bendix $(1967,1978)$ and is usually used in the sense of 'a model nation from which to borrow elements'. In PISA research the term is frequently linked with societies or systems that become popular by virtue of their achievements in international comparisons and which are thus emulated in other systems in order that they, too, should do well in future competitions. Scholars assert that this construction (or reconstruction) of reference societies involves a shift from an historical basis of reference to a performance or test-based reference, coupled with scalar and quantitative shifts to include more national and subnational systems as reference points (Adamson, Forestier, Morris, \& Han, 2017; You \& Morris, 2016). For example, Sellar 
and Lingard (2013) argue that the inclusion of Shanghai in the PISA 2009 assessment changed considerably the ways in which exogenous systems were referenced in national education policy debates. Where Finland was the flagship of PISA performance from 2000 until 2006, Shanghai's overwhelming success in the PISA 2009 tests set off a 'PISA-shock' around the globe. The outstanding performance of Shanghai in 2009, following the creditable performances of other Asian systems in 2006, caused a far-reaching shock prompted by a the unexpectedly strong performance of a foreign system. According to the authors, countries such as the USA, England and Australia in particular turned increasingly to China and gradually to other high performing Asian countries for an external rationalization for national reforms in schooling geared to improving comparative international performance (Sellar \& Lingard, 2013, p. 465).

Such studies are not without reason. Yet existing research has also shown that although international assessment information, such as that disseminated through PISA, attracts attention in domestic contexts, it does not mean that the reform ideas advocated thereby are entirely new to the national agendas. Quite the contrary, as emphasized, by policy externalization scholarship, references to the global community, for example, to large-scale international learning assessments and the best practices thereby promoted, are often used as discursive tools by which to legitimize already planned policy reforms (Steiner-Khamsi, 2004; Waldow, 2009). This means that local actors do not merely react to exogenous policy models in order to learn from the international best practices. If anything, they resort to cross-national comparisons and other 'external' information to legitimize policy ideas already on the table.

In her study on the local uses of PISA, Steiner-Khamsi (2003) argues that this was indeed the case in Germany after the release of the first PISA findings. In Germany debates about introducing standards, accountability measures, quality monitoring, expanding school choice and school-based management were already under way before the release of the first PISA findings. For a variety of reasons, however, these reform initiatives were perceived as highly controversial at the domestic level. Therefore, German policymakers favouring these reforms needed an additional source of legitimation or an 'external authority' that would provide them with the much-needed justification for introducing such controversial education reforms. Germany's poor ranking in PISA served as just such a legitimation tool. According to Steiner-Khamsi, PISA and Germany's poor ranking in it provided ingredients for an ideal policy strategy to exert 'external pressure' for justifying and accelerating massive education reforms in Germany (Steiner-Khamsi 2003, 4-5).

These observations are interesting and challenge us to examine the role of IOs in domestic policymaking more analytically. In other words, if many of the ideas and calls for reform put forward in connection with PISA have in one way or another been part of the national education debate, why should it be that they are presented as legitimate in association with the national PISA debate? What other entities are used as resources in political rhetoric and what accounts for their popularity in 
national politics? These are the questions to which I, too, seek answers in my analysis of the ways in which Finnish education has been criticized at different times in the context of debating PISA.

The neoinstitutionalist epistemic governance framework (Alasuutari \& Qadir, 2014, 2016) affords useful tools for making sense of the role of IOs in domestic political argumentation. The framework starts with the premise that in the contemporary world actors seeking to influence domestic policymaking typically work on others' conceptions of reality, proper normative principles and identity construction (Inda, 2005). In fact, the theory argues that, apart from the use of sheer force with no other objective or effect than removing a physical obstacle, most social relations can be viewed from the perspective of epistemic governance (Alasuutari \& Qadir, 2014, p. 71). ${ }^{2}$ Part of this 'epistemic work' entails utilizing prevailing conceptions of the social world, for instance those wielding power in society. In their attempts to exert influence, speakers construct and appeal to facts, principles or entities that they assume others deem unavoidable determinants of the situation, or they cite sources assumed to lend credibility to the claims and proposals made. In other words, actors wishing to influence lean on others' authority by referring to them: by presenting a framing of reality that utilizes authoritative views and actors (Alasuutari, 2018).

The understanding of authority in epistemic governance theory does not denote one's right or privilege to impose one's will on others. Instead, it signifies anything that actors use and utilize to influence others' conceptions of the world and of what is desirable. It denotes the recognition among the actors of someone or something worthy of note when considering one's own conduct. This means that actors may present themselves as powerful or claim authority for themselves, but they may also make use of authorities and authoritative principles, thus struggling for a hegemonic conception of the situation that significantly affects others' views and behaviour (Alasuutari, 2018). Such exerting of influence is referred to as epistemic governance because it functions through knowledge and its validation (Alasuutari \& Qadir, 2014). Those who are better positioned to exert influence over the understanding of others as to what is true and desirable are also in a position to influence the decisions taken on such issues.

According to the theory, the authority of IOs is useful in attempts to influence others' conceptions of the social world and of desirable policies. Borrowing the prestige of international governmental (IGO) or nongovernmental organizations (INGOs) is useful in affecting others' views because they represent a large body of members and a set of collectively agreed ideals and principles (Alasuutari, 2018, p. 9).

\footnotetext{
2 This framework developed in epistemic governance theory is greatly indebted to the theories on 'governmentality' inspired by Foucault (Foucault, 1991; Foucault, Burchell, Gordon, \& Miller, 1991) who also emphasize the use of subtle techniques of governance in democratic national states (Foucault, 2007; Rose \& Miller, 1992) and how even authoritarian regimes are increasingly susceptible to global public opinion in the compression of global political processes. However, epistemic governance adds to these existing theories as it also examines what this epistemic persuasion consists of and how it mobilizes popular notions.
} 
When it is feasible to present some political idea as enjoying the approbation of a wider, for example, scientific authority, it comes to resemble an uncontested fact unrelated to domestic policy. We may argue that this is also the very reason for the existence of IOs. Actors seeking to influence domestic policies establish IOs and other international networks and take part in their activities since they deem it prestigious to do so and because the prestige or authority of these bodies is useful in the pursuit of policy interests. Once organizations and networks are institutionalized, various actors can use their authority to legitimize their own policy objectives (Alasuutari, Rautalin, \& Syväterä, 2016). ${ }^{3}$

To understand how authority is created and vested in organizations such as the OECD, we need to bear in mind that authority is a relational concept, based on recognition on the part of others. The epistemic governance scholarship asserts that it can be built on four distinct grounds: authority can be ontological, moral, capacity-based and/or charismatic (Alasuutari, 2018, pp. 3-4). Ontological authority refers to the prestige of a source of reliable information about reality, typically based on scientific research and expertise. Moral authority rests with an actor or other entity consulted or referred to as a source dispensing guidance on what is right or acceptable. Capacity-based authority entails deference based on perceived competence (e.g., an actor's ability to accomplish actions such as lending money or accomplishing a military operation). Finally, charismatic authority is based on characteristics unique to a certain individual or organization. It may be built on the exceptional sanctity, exemplary character, or heroism of an individual, but it can also be said that modern-day celebrities possess charismatic authority in that whatever a celebrity or well-known organization does is of interest to many people and may provide an example for those who admire that entity.

Empirical analysis of how much politicians in various countries refer to IOs as authorities to justify their views shows that these organizations have differing profiles in this respect (Alasuutari, 2016, pp. 116-129). For example, the OECD is typically referred to as an expert organization and hence as an ontological authority. Its authority rests on its vast research capacity when compared with others, which modern individuals assume enables the organization to tell us what our world is about and thus highlight certain trends, identify common problems and map out a range of appropriate solutions (Henry, Lingard, Rizvi, \& Taylor, 2001; Mahon \& McBride, 2008).

Whatever an organization's specialization may be, it takes time and resources to build authority that others widely acknowledge. For instance, authority based on scientific expertise requires abundant production of knowledge of a high standard. Yet what ultimately counts is not the money or time expended on building an entity but whether others do indeed regard it as an authority: whether its

\footnotetext{
3 The argument put forward here comes close to those evinced in the 'epistemic communities' approach. The epistemic communities approach has stressed the role of scientists and policy-makers to whom policy-makers in different states turn for advice: when a network of professionals with recognized expertise and an authoritative claim to policy-relevant knowledge within a particular domain share a set of normative and principled beliefs, they influence the coordination of state policies (Dunlop, 2009; Haas, 1992; Miller \& Fox, 2001).
} 
pronouncements or actions are taken into account and referred to in others' deliberations on their choices. If the OECD should be unsuccessful in its mission to produce information that is actively taken into account when domestic systems are designed, its credibility and so also its authority in national politics will vanish. In that sense, the authority of an entity is similar to social capital as discussed by Putnam and colleagues (1993, p. 170): it increases with use and diminishes with disuse.

References to the OECD and its knowledge production in the national public are of particular interest from this perspective. It is through such references to the international community and to the OECD aiming to act as a scientifically or otherwise prestigious agent, that the authority of the organization is actualized (Rautalin, Alasuutari, \& Vento, 2018). The authority of the OECD and the knowledge production of its PISA project are a case in point. The authority of the organization is manifest in and constructed through domestic actors' actions in domestic debates, in which they (often selectively and purposefully) invoke PISA and other 'legitimate' information in their endeavours to convince other parties of the status of national systems and of desired policy measures.

\section{Data and Methods}

In my analysis of the criticism levelled at Finnish education and of the justifications used, I use as my data media texts with references to PISA appearing in Finnish quality media. The data was collected from three central national quality media outlets; Helsingin Sanomat, Suomen Tietotoimisto and Suomen Kuvalehti and from the periods December 2001 - April 2009 and December 2013 - December 2014. The earlier period covers the PISA debate from a period during which Finland ranked high in PISA learning assessments. The latter period covers debates during which Finland's PISA ranking deteriorated drastically. In collecting my data, I made no distinction between the arguments evinced in the traditional news stories and those in the letters to the editor. Rather, I saw all arguments put forward in the context of discussing PISA as reflections of how the issue is discussed in the national public.

In order to analyse how the criticism expressed, I concentrate in my analysis on only those texts in which allegations are made about problems in the Finnish education system. In the interests of working economically I used random sampling to extract from this mass a smaller sample which I took for closer scrutiny. In compiling my sample, I ensured that I had a sufficient number of media texts from the time when Finland was ranked high in PISA and also from the time when Finland's ranking was clearly poorer than before. My total sample comprised 136 items. From these I coded all types of justifications for criticism of the Finnish education system. In coding the texts, I kept the two time periods separate. This way I eventually had two distinctive codings, each representing different justifications used for criticizing Finnish education. The different types of justification were not mutually exclusive. Rather, by coding each story I marked all the justifications used to criticize the status of national education. This way, one item could be coded to several, parallel typologies. 
The method applied in my analysis relates closely to the approach broadly known as rhetorical analysis (Billig, 1987; Perelman \& Olbrechts-Tyteca, 1969). In my analysis, I paid special attention to the modes of justifications in the various arguments evinced by various audience members perceived to be so convincing or 'shared' that they are taken up and reported by the media. This assumes importance as I seek to ascertain what arguments work well as tools in epistemic reassurance work in the national public. As has been discussed earlier, arguments that appear widely convincing typically start to inform the overall publicity surrounding the reported event and possibly the related policy decisions to be made.

\section{PISA only tells part of the truth about Finnish education}

On 4 December 2001, the OECD published its first PISA results. At the same time, each participating country issued its own national PISA press release focusing on country-specific results. In Finland, the national PISA press release was published by MINEDU in co-operation with the Finnish Institute for Educational Research. Interestingly, the first PISA accounts released by central government included a warning not to make too much of Finland's PISA ranking. Indeed, the implication was rather that Finland's top ranking in the mother tongue assessment might be attributable to chance (see e.g. Liiten, 2004). The central government's caution in accounting for the high PISA scores may be due the fact that a little earlier the NBE had published an assessment report according to which Finnish pupils' reading achievements were alarmingly poor. It appears that those parties for whom the results of the national evaluation were politically useful aimed to downplay the results achieved in PISA (Anonymous, 2005).

Although the central government was initially circumspect in its PISA accounts, this was not the case later. As public interest in Finnish education grew and as Finland further improved its ranking in PISA, the central government assumed a more prominent role in the national PISA debate. What all these later claims by central government about PISA have in common is that Finnish basic teaching was seen to have been very successful, indeed the best in the world. This success of basic teaching was attributed to Finland's highly successful and consistent education policy. As emphasized earlier, in the central government's accounts, the role of the comprehensive school reform introduced in the 1970's was especially emphasized. The reports also referred to the fact that in Finland all teachers have a master's degree in education. In discussing the possible problems in Finnish education, these were mainly claimed to be in areas outside the purview of central government.

This image conveyed through PISA of Finnish education as being of an internationally high standard and almost free from any defects was clearly not to the advantage of those actors in whose opinions there was a great deal of room for improvement in national education. Finland's success in subsequent rounds of PISA and the accompanying image of Finnish education as internationally excellent deprived of their credibility all those accounts containing claims about problems in Finnish education. 
To challenge the understanding rooted in the general public of Finnish education and policy as highly successful, critics resorted to creative rhetoric. For one thing, they acknowledged the understanding embedded in the national (and also the international) discussion of PISA of Finnish education being of high quality. However, they attempted to disprove this understanding by introducing into the discussion themes or views that supported the claim that Finnish education is not problem-free. One of the most frequently used strategies in this connection was to refer to subjects or phenomena traditionally deemed serious and prone to give rise to discussion in the Finnish public sphere. In their argumentation, critics referred, for instance, to young people's increased mental problems and violent behaviour. References were also made to the news about teachers' overwhelming workloads and increased burnouts. The purpose of invoking such views was simply to argue that the image of Finnish education as conveyed through PISA is imperfect and that there are (serious) problems in Finnish schooling. The Helsingin Sanomat letter to the editor below is one example of such argumentation. In the text, a Finnish professor of philosophy acknowledges Finland's top rank in the assessment. However, he also asserts that PISA does not measure all the skills required in future societies. He emphasizes that young people's mental health and social faculties are not addressed in PISA evaluations and argues that is in just these that Finnish school children have problems.

In mid-December, I attended an education conference in Germany. The issue of why Finnish schoolchildren managed best in the OECD PISA tests while the Germans were left to bring up the rear provoked a surprisingly heated debate. On being asked for an explanation I rendered something like the following extempore. The fine old tradition which operates in Finland is that teachers and schools here are relatively independent in the work they do. (...)

Finally, I tried to console people from other countries that the PISA tests covered a decidedly narrow range of the pupils' achievements in mathematics and reading. Success in work and in life are dependent upon a much wider range of abilities, perhaps first and foremost those in mental health and social skills. In these the Finnish school system needs to do a lot more. (Helsingin Sanomat, Opinion, December 27, 2001)

The second frequently deployed strategy to substantiate claims about problems was to refer to other studies (other than PISA) on the state of Finnish schooling and the shortcomings mentioned therein. Critics referred, for instance, to shortcomings highlighted by other international learning assessments or to those emphasized in national evaluations. Likewise, speakers invoked the deficiencies revealed by rankings conducted at other levels of education, such as higher education rankings and rankings conducted in early childhood education. The idea of invoking other studies and comparisons was simply to prove that although Finland ranked high in PISA there was research-based evidence of problems in Finnish education system. The Suomen Tietotoimisto news text below is an example of such convincing work. The text compares the PISA results for mother tongue in Finland and those of earlier international and national comparisons of learning outcomes. The text notes the findings of national comparisons of learning outcomes according to which young Finns have serious problems with the basics of the mother tongue. The text also makes reference to an observation made in the same study about demographic disparities in learning outcomes between areas. The results of these 
national assessments of learning outcomes are used as tools in building an image of Finnish basic teaching as fraught with problems and even as causing inequality.

In the joint tests of the OECD PISA survey (2000) Finnish schoolchildren proved to be the best readers, third best in natural sciences and fourth best in understanding mathematics. A little earlier another international survey, TIMMS (1999) reported that Finns' skills in mathematics and natural sciences were a good average. (...) In the national evaluation conducted by the Finnish National Board of Education (NBE) the achievements of ninth graders was pretty much average.

(...) In the national evaluations 15-20 per cent of ninth graders were inexcusably poor in basics. For example, it emerged in the evaluation of the mother tongue that in spite of reasonably good literacy skills writing and grammar posed problems for schoolchildren. Pupils did clearly better than average in more prosperous municipalities and urban areas than in deprived areas. (Suomen Tietotoimisto, Domestic news, May 21, 2002)

The third and final prominent way of justifying criticism in the context of debating PISA was to refer to the PISA Study itself and the shortcomings it has highlighted. The argument put forward in this context was that PISA also highlighted shortcomings in Finnish education. Discussions in the media emphasized themes such as young Finns' failure to enjoy their schooldays, their lack of faith (especially among girls) in their own mathematical skills and gender differences in skills in the mother tongue. These observations as evinced by PISA were used as justifications to legitimize the call for distinct policy reforms. The news text below is an example of such rhetoric.

Finland's high ranking in last autumn's OECD countries' school comparison is heartwarming. However, PISA revealed differences, among others, between girls' and boys' skills in the mother tongue.

"This concerns basically all pupils. A pupil who is doing well is not necessarily happy," says Ms. Eeva-Riitta Pirhonen of the Ministry of Education and Culture.

According to Ms. Pirhonen it is also worrying that according to research Finnish children and young people do not enjoy school as a whole. (Suomen Tietotoimisto, Politics, February 8, 2004)

To sum up, when Finland was successful in the PISA assessments and when international interest in Finnish education and education policy was high, there was no credibility in suggesting that Finnish education was in need of reform. In order to assure the public at large that there was nevertheless a need for reforms, critics fell back on a tried and trusted rhetoric. In their protestations, they conceded the conception rooted in public in connection with PISA of the excellence in international comparison of Finnish basic education. However, then an attempt was made to challenge this image of a successful system by reference to other investigations or themes which served to foster an image of problems in the system. Use was made in particular of themes generally regarded as serious by the Finnish public, among them that children and young people were not doing well and that teachers were suffering from job stress. Claims about problems in the education system were accompanied by references to research pinpointing possible flaws in the Finnish education system. Elements were also picked out from PISA to confirm the image of Finnish education as less than perfect. 


\section{PISA as a proof of problems in Finnish education}

On 2 December 2013 the OECD published its fifth PISA results. In these Finland had dropped in all areas measured to the bottom of the top third. PISA 2009 results have already shown a downturn in national learning outcomes. Yet the downturn in the PISA 2012 results was more marked. The most noticeable downturn was in mathematics, where the ranking was ten places lower than in the previous round, when mathematics and was the main object of evaluation.

As in earlier years, MINEDU published its press release commenting on the national PISA results. Interestingly, unlike in earlier years, when central government was active in accounting for the factors behind the national PISA results, this press release featured no discussion on why Finland's PISA results had declined. Nor did the press release specify what concrete measures were to be taken by central government to improve national learning outcomes in the future. In MINEDU's press release reference was made to an earlier observation made in PISA, according to which attitudes towards school had become less positive among Finnish pupils and in Finnish society alike. Likewise, the press release emphasized the lack of motivation in learning and studying also evinced by PISA. The press release left entirely open how these aspects noted by PISA and the general decline in learning outcomes might be remedied (MINEDU, 2013).

This drastic fall in the PISA rankings and the inability of the national political elite to provide credible explanations for this decline in learning outcomes afforded an incomparable negotiation position for those actors in whose opinion there are problems in Finnish education. While in earlier years those dissatisfied with education were obliged to have recourse in their rhetoric to themes and investigations which challenged the image of Finnish education as a success, after the findings of PISA 2012 were published the evaluation itself served as a highly efficient tool with which to expose the challenges in education. My media text analysis revealed that after the release of PISA 2012 findings, the lower PISA ranking was indeed the most used tool in justifying claims about problems in Finnish schooling. In no less than 89 per cent of the sample texts, Finland's PISA ranking was used to make an argument that all was not well in Finnish education.

The Suomen Tietotoimisto news text below is an example of such rhetoric. In this extract the representative of the Teacher Student Union of Finland (prospective teachers) mentions Finnish basic teaching and the highly skilled teachers as factors which in the public debate have frequently been deemed crucial to Finland's success in PISA. She argues that these areas were never further developed, and that this is now apparent in the poorer PISA results. In the text, the blame is put on Finnish policy-makers who, according to the speaker, have not allocated sufficient resources to the development work.

Finland's former success in PISA has been attributed among other things to the high level of education among teachers. 
"Finland has rested on its laurels, confident that with the present system we can manage and need change nothing. There should have been development work going on all the time, but the money ran out," says union leader of Teacher Student Union of Finland, Ms. Julia Petäjä. (Suomen Tietotoimisto, Domestic news, December 1, 2013)

Although the lower PISA ranking placed a useful weapon in the critics' hands with which to justify the criticism, this does not mean that other tools were used in the defence of claims of the challenges faced by teaching. As in earlier years, in this later debate, too, other studies were frequently invoked to justify the claim that all is not well in Finnish education. The main argument put forward in this context was that others studies have also revealed problems in national education. The Helsingin Sanomat news text below is an example of such rhetoric. In the text, the Chairman of the of the Finnish teachers' trade union refers to studies conducted by central government, which, according to him, have shown development similar to that reported in the PISA findings. In the text, the downturn in PISA ranking is claimed to be due to cuts in funding for education made by Finnish municipalities.

The teachers' trade union is in no way surprised at the decline in Finland's schoolchildren's PISA ranking says Chairman Olli Luukkainen. He predicts that, due to the layoffs by the municipalities affecting the schools, this negative trend in PISA will continue.

"I fear discrepancies in the municipalities and the schools. In some municipalities, the pupils may be almost on their own for one and even two months."

According to Mr. Luukkainen there have already been signs of a decline in the standards among Finnish schoolchildren in surveys conducted by the National Board of Education. (Helsingin Sanomat, Domestic news, December 1, 2013)

My analysis of the media texts showed that when Finland fared decidedly worse in PISA and when the national political elite was no longer able to take a credible stand on the reason for this, those dissatisfied with the national education system seized the opportunity and took advantage of it in their efforts to bring about various educational reforms. Whereas criticism had hitherto been based almost exclusively on the claim that PISA does not tell the whole truth about Finnish education, after the release of the PISA 2012 results the main source of criticism became Finland's poorer PISA ranking. The central argument put forward in this context was that PISA is proof of problems in Finnish schooling. The reason why the PISA ranking was now such a potent tool is, of course, the prominent role the survey had been accorded in the Finnish public discussion. Whereas in the earlier discussion on education PISA was so inextricably linked to the success of the national education system and of education policy, so also did PISA and the decline in Finland' ranking serve as a legitimate weapon in justifying claims about the failure of education and the related decision-making. As in earlier years, and also as the PISA ranking changed, allegations of problems were also backed up with references to other evaluations and studies on education. 


\section{Discussion}

In this study, I set out to examine the Finnish media debate surrounding the OECD-led PISA Study during the periods 2001-2009 and 2013-2014. The empirical focus of the study was on how debaters dissatisfied with Finnish education have justified their criticism in the context of debating PISA and how the justifications used have changed as Finland's PISA ranking has changed. The analysis revealed that as Finland ranked high in PISA's early rounds and as the ensuing public discussion on the PISA findings turned into a discussion on the excellence of Finnish basic education and education policy, the opposite view, which was extremely critical of the national education and policy, became very difficult to promote in the national public. In order to justify the need for reform the reformists were compelled above all to find means to challenge the image of Finnish education and education policy as successful. As to the specific means deployed, the reformists invoked themes or topics that are considered authoritative and sacred among the public at large. For instance, critics referred to how children and young people were not doing well, and to teachers' increased work stress. These themes were deployed as weapons to argue that in spite of success in PISA, there are (serious) problems in Finnish education. Moreover, the reformists invoked the shortcomings identified by PISA and other studies and used these as a justification for various reforms.

As Finland's ranking in PISA 2012 changed markedly, it lent great support to the critical arguments voiced in public in Finland. While in earlier years support for criticism had been sought mostly outside the PISA discourse, the point of departure for criticism was now the evaluation itself and the clear decline in Finland's ranking. The use value of PISA in defending criticism stemmed from the very importance previously attached to it in the national education discourse. As in earlier years, in this later debate, too, claims about problems were complemented by references to other scientific evidence.

What was also of especially great help in publicising critical views on education in Finland after PISA 2012 was that the national political elite, which had long succeeded in directing the national public PISA discussion, were unable in the face of the changed ranking to offer convincing explanations for this change in the ranking or to propose what measures should be undertaken in consequence. In other words, the obvious decline in the national PISA ranking and the inability of the previously so well placed political elite to take over the public debate on the changed PISA rankings opened up negotiating space for a critical discussion on education for which there had been decidedly less room in the earlier publicity surrounding PISA.

With my analysis of the ways in which Finnish education has been criticized at different times in the context of debating PISA, and of how the justifications used have changed as the ranking results have changed, I also wanted to contribute to the wider theoretical debate on the role of IOs in domestic policies. I approached the question from the perspective of a neoinstitutionalist epistemic governance framework and argue that IOs and their special projects gain their agentive capacity in domestic 
policies when local actors refer to them, i.e. when actors in domestic sites use and wield their authority in their attempts to convince others of the state of domestic systems and of desirable policy solutions. The OECD and its PISA project are cases in point. PISA's popularity in domestic policies stems from the OECD's long-standing expert position, from the organization's ability to accurately evaluate the skills and competences of schoolchildren nearing the end of their compulsory education. By systematically assessing these skills cross-nationally (and ever increasingly the skills of other age groups, too), the OECD has become a highly respected, if not charismatic, actor in contemporary policy-making.

Yet the organization has no role in domestic policies unless reference is made to it in national political argumentation. The role of the OECD comes into being only when it and its knowledge production are taken seriously, i.e. when it is considered that the ideas and best practices marketed by the organization can contribute something new to the existing domestic debate or something which enhances the credibility of the argumentation and so its ability to convince. In this way the OECD, like the national actors, plays a role in processes in which national policies come into existence, albeit in such a way that the OECD would appear to exert influence over national policies through the authority or epistemic capital (Alasuutari et al., 2016) it lends for domestic political argumentation.

As has been discussed in this study, the authority of such an international organization or its potential as a tool for exerting influence may favour some actors over others. When the OECD's PISA Study and the public debate it inspired speak on behalf of a certain policy and reforms, those opposed to such policy and reforms may be pressed to defend their views. However, this does not mean that such political ideas and interpretations so deriving their position of authority are beyond challenges in the national political rhetoric, nor that they are unassailable in such negotiations by other entities and their epistemic leverage.

As emphasized by epistemic governance theory, and discussed several times in this study, actors wishing to influence existing policies are creative in their persuasion work: they make use of all possible actors and values considered sacred or authoritative among the participants, thus accumulating epistemic capital behind the projects they seek to promote (Alasuutari, 2018, p. 4). Each reference (be it positive or negative) to such actors and values also adds to their prestige and credibility and thus to their ability to convince. After all, as a relational construct, the authority of an entity is built on belief and credibility, and it increases through use.

\section{References}

Adamson, B., Forestier, K., Morris, P., \& Han, C. (2017). PISA, policymaking and political pantomime: education policy referencing between England and Hong Kong. Comparative Education, 53(2), 192-208. doi:10.1080/03050068.2017.1294666 
Afonso, N., \& Costa, E. (2009). The influence of the Programme for International Student Assessment (PISA) on policy decision in Portugal: the education policies of the 17th Portuguese Constitutional Government. Sísifo. Educational Sciences Journal, 10, 53-64.

Alasuutari, P. (2016). The Synchronization of National Policies: Ethnography of the Global Tribe of Moderns. London: Routledge.

Alasuutari, P. (2018). Authority as epistemic capital. Journal of Political Power. doi:10.1080/2158379X.2018.1468151

Alasuutari, P., \& Qadir, A. (2014). Epistemic governance: An approach to the politics of policy-making. European Journal of Cultural and Political Sociology, 1(1), 67-84. doi:10.1080/23254823.2014.887986

Alasuutari, P., \& Qadir, A. (2016). Imageries of the Social World in Epistemic Governance. International Sociology, 31(6), 633-652.

Alasuutari, P., Rautalin, M., \& Syväterä, J. (2016). Organisations as Epistemic Capital: the Case of Independent Children's Rights Institutions. Journal of Politics, Culture, and Society, 29(1), 57-71.

Anonymous (2005). [Role of PISA in Finnish Education Policymaking].

Bendix, R. (1967). Tradition and Modernity Reconsidered. Comparative Studies in Society and History, 9(3), 292346.

Bendix, R. (1978). Kings or People: Power and the Mandate to Rule. Berkeley: University of California Press.

Bieber, T., \& Martens, K. (2011). The OECD PISA Study as a Soft Power in Education? Lessons from Switzerland and the US. European Journal of Education, 46(1), 101-116.

Billig, M. (1987). Arguing and thinking : a rhetorical approach to social psychology. Cambridge ; New York

Paris: Cambridge University Press ;

Editions de la Maison des sciences de l'homme.

Bonal, X., \& Tarabini, A. (2013). The role of PISA in shaping hegemonic educational discourses, policies and practices: the case of Spain. Research in Comparative and International Education, 8(3), 335-341.

Deutsches PISA-Konsortium. (2001). PISA 2000: Basiskompetenz von Schülerinnen und Schülern im internationalen Vergleich Retrieved from Opladen:

Dunlop, C. (2009). Policy transfer as learning: capturing variation in what decision-makers learn from epistemic communities. Policy Studies, 30, 289-311.

Ertl, H. (2006). Educational standards and the changing discourse on education: The reception and consequences of the PISA study in Germany. Oxford Review of Education, 32(5), 619-634.

Foucault, M. (1991). Governmentality. In G. Burchell, C. Gordon, \& P. Miller (Eds.), The Foucault Effect: Studies in Governmentality (pp. 87-104). Chicago: University of Chicago Press.

Foucault, M. (2007). Security, territory, population: Lectures at the College de France, 1977-78. Basingstoke: Palgrave Macmillan.

Foucault, M., Burchell, G., Gordon, C., \& Miller, P. (1991). The Foucault effect : Studies in governmentality: With two lectures by and an interview with Michel Foucault. Chicago: University of Chicago Press.

Fredriksson, U., Holzer, T., McCluskey-Cavin, H., \& Taube, K. (2009). Strengths and weaknesses in the Swedish and Swiss education systems: A comparative analysis based on PISA data. European Educational Research Journal, 8(1), 54-68.

Haas, P., M. (1992). Banning Chlorofluorocarbons: Epistemic Community Efforts to Protect Stratospheric Ozone. International Organization, 46(1), 187-224.

Henry, M., Lingard, B., Rizvi, F., \& Taylor, S. (2001). The OECD, Globalisation and Education Policy. Amsterdam: The International Association of Universities Press and Pergamon Press.

Inda, J. X. (2005). Analytics of the Modern: An Introduction. In J. X. Inda (Ed.), Anthropologies of Modernity: Foucault, Governmentality, and Life Politics (pp. 1-20). Oxford: Blackwell.

Kupiainen, S., Hautamäki, J., \& Karjalainen, T. (2009). Finnish Education System and PISA. Helsinki: Ministry of Education. 
Liiten, M. (2004). Pisa-pirskeissä pidettiinkin ikävää. Helsingin Sanomat, 12 December, Domestic news.

Mahon, R., \& McBride, S. (2008). Introduction. In R. Mahon \& S. McBride (Eds.), The OECD and Transnational Governance (pp. 3-22). Vancouver, Toronto: UBC Press.

Mangez, E., \& Hilgers, M. (2012). The Field of Knowledge and the Policy Field in Education: PISA and the production of knowledge for policy. European Educational Research Journal, 11(2), 189-205.

Martens, K., \& Niemann, D. (2013). When Do Numbers Count? The Differential Impact of the PISA Rating and Ranking on Education Policy in Germany and the US. German Politics, 22(3), 314-332. doi:10.1080/09644008.2013.794455

Miller, H. T., \& Fox, C. J. (2001). The Epistemic Community. Administration \& Society, 32(6), 668-685.

MINEDU. (2013). PISA 2012: Proficiency of Finnish youth declining. Finnish Ministry of Education and Culture Retrieved from http://www.minedu.fi/OPM/Tiedotteet/2013/12/pisa.html?lang=en.

OECD. (2001). Knowledge and skills for life: First results from PISA 2000. Paris: OECD.

OECD. (2004). Learning for tomorrow's world: First results from PISA 2003. Paris: OECD.

OECD. (2007). PISA 2006. Science Competences for Tomorrow's World. Volume 1. Paris: OECD.

OECD. (2010). PISA 2009 Results. What Students Know and Can Do: Student Performance in Reading, Mathematics and Science. Volume 1. Paris: OECD.

OECD. (2013). PISA 2012 results in focus: What 15-year-olds know and what they can do with what they know. Paris: OECD.

Perelman, C., \& Olbrechts-Tyteca, L. (1969). The new rhetoric: a treatise on argumentation. Notre Dame, [Ind.]: University of Notre Dame Press.

Pons, X. (2012). Going beyond the 'PISA Shock' Discourse: An analysis of the cognitive reception of PISA in six European countries, 2001-2008. European Educational Research Journal, 11(2), 206-226.

Putnam, R. D., Leonardi, R., \& Nanetti, R. Y. (1993). Making Democracy Work: Civic Traditions in Modern Italy. Princeton: Princeton University Press.

Rautalin, M. (2014). The role of PISA publicity in forming national education policy: The case of Finnish curriculum reform. In P. Alasuutari \& A. Qadir (Eds.), National Policy-making: Domestication of Global Trends (pp. 95-110). London: Routledge.

Rautalin, M., \& Alasuutari, P. (2007). The curse of success: The impact of the OECD's Programme for International Student Assessment on the discourses of the teaching profession in Finland. European Educational Research Journal, 6(4), 348-363.

Rautalin, M., \& Alasuutari, P. (2009). The uses of the national PISA results by Finnish officials in central government. Journal of Education Policy, 24(5, September 2009), 539-556.

Rautalin, M., Alasuutari, P., \& Vento, E. (2018). Globalisation of education policies: does PISA have an effect? Journal of Education Policy. doi:10.1080/02680939.2018.1462890

Rose, N., \& Miller, P. (1992). Political Power Beyond the State: Problematics of Government. British Journal of Sociology, 43(2), 173-205.

Sahlberg, P. (2011). PISA in Finland: an education miracle or an obstacle to change? CEPS Journal, 1(3), 119140.

Sellar, S., \& Lingard, B. (2013). Looking East: Shanghai, PISA 2009 and the reconstitution of reference societies in the global education policy field. Comparative Education, 49(4), 464-485.

Steiner-Khamsi, G. (Ed.) (2004). The Global Politics of Educational Borrowing and Lending. New York: Teachers College Press.

Takayama, K. (2008). The politics of international league tables: PISA in Japan's achievement crisis debate. Comparative Education, 44(4), 387-407.

Takayama, K., Waldow, F., \& Sung, Y.-K. (2013). Finland Has it All? Examining the Media Accentuation of 'Finnish Education' in Australia, Germany and South Korea. Research in Comparative and International Education, 8(3), 307-325. doi: 
Waldow, F. (2009). Undeclared imports: silent borrowing in educational policy-making and research in Sweden. Comparative Education, 45(4), 477-494.

Winstanley, C. (2012). Alluring Ideas: Cherry Picking Policy from Around the World. Journal of Philosophy of Education, 46(4), 516-531.

You, Y., \& Morris, P. (2016). Imagining school autonomy in high-performing education systems: East Asia as a source of policy referencing in England. Compare: A Journal of Comparative and International Education Review, 46(6), 882-905. doi:10.1080/03057925.2015.1080115 